\title{
Which environment makes cancer?
}

\author{
Suleyman Kaleli*, Asuman Deveci and Gamze Guney Eskiler \\ Faculty of Medicine, Department of Medical Biology, Sakarya University, Turkey
}

\begin{abstract}
Cancer occurs with uncontrolled cell growth or abnormal cell division in DNA damage. Carcinogens are the factors that cause DNA mutations and they are known to cause cancer in our body by making changes in gene level. Genetic susceptibility is also important in cancer development along with factors such as poor living conditions. Additionally, all these environmental factors such as X-rays, gamma rays, the radiation emitted from radioactive materials, aniline type dyes, cigarette, free radicals, asbestos, silica dust, air pollution, food additives, various drugs, some of the chemicals used in perfumes, oncogenic viruses and bacteria are playing an important role in cancer formation and contribute the increase of incidence of cancer. The environmental factors that cause cancer are located in air, water, soil and the food that we need to live. Consequently, human get cancer from exposure to carcinogens from the environment where they live. The cancer is a difficult disease to treat and reduces the life quality of people with cancer. Investigation of the effects of environmental factors in cancer and prevention of the cancer development by determining the factors that cause cancer are very important from this perspective.
\end{abstract}

\section{Introduction}

Cancer, which is the second leading cause of death, is a group of disease involving abnormal cell growth with the potential to invade or spread to other parts of the body [1,2]. According to GLOBOCAN, there were about 14.1 million new cancer cases, 8.2 million cancer deaths and 32.6 million people living with cancer within 5 years of diagnosis in 2012 worldwide. On the other hand, it is estimated that $1,685,210$ new cases of cancer will be diagnosed in the United States and 595,690 people will die from the disease in 2016. Thus, there is an urgent need for a new therapeutic strategy to reduce cancer-related deaths $[3,4]$.

Cancer is a multifactorial disease. Most genetic factors and environmental factors such as viruses, bacteria, radiation and eating habits and chemicals increase the risk of developing cancer [3-8] (Figure 1). $10-15 \%$ of all cancers are thought to be related to heredity, as for the rest, $85-90 \%$ of cancer have their roots in the environment and lifestyle.

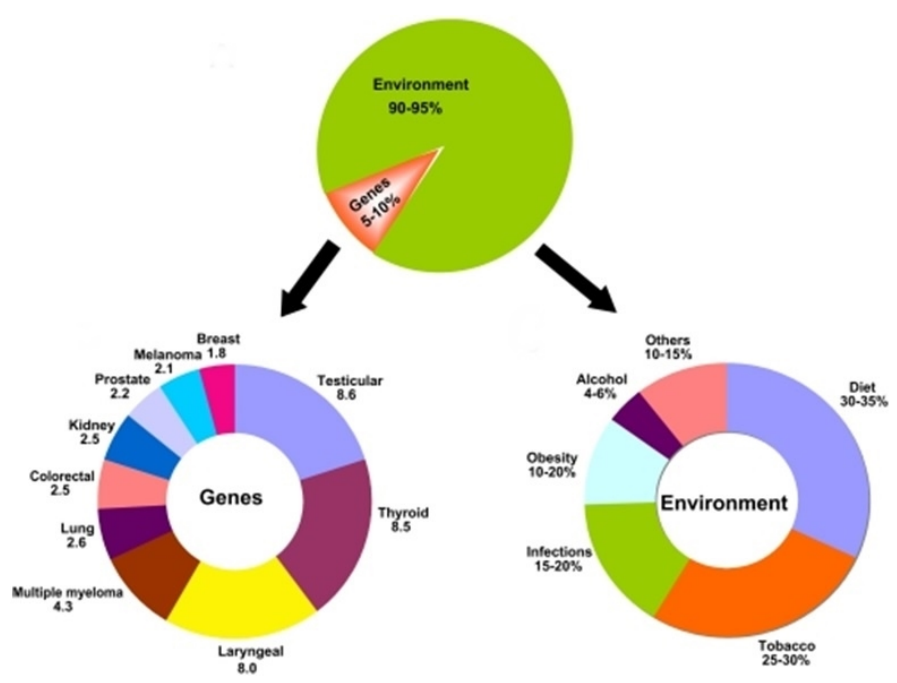

Figure 1. The role of genes and environment in the development of cancer [9]
It is known that approximately $25-30 \%$ of tobacco, $30-35 \%$ of diet, $15-$ $20 \%$ of infections and the remaining percentage of other factors like radiation, stress, physical activity, environmental pollutants, etc. cause cancer related mortality [9]. In terms of genetic factors, the mutations in multiples genes, including oncogenes, tumor suppressor genes and DNA repair genes can lead to cancer formation rather than a single gene. These genes cause cancer through three main biologic pathways [cell cycle, apoptosis and differentiation], which are normally, regulate tissue homeostasis and cell growth [9]. For this purpose, the aim of this study was to discuss the interactions of genetic factors with various environmental factors, including diet, lifestyle, metabolic alterations, and various environmental exposures.

\section{The relationship between cancer and genetics}

Inherited genetic factors play an important role in cancer development. The mutation of critical genes, including tumorsuppressor genes, oncogenes and genes involved in DNA repair, leads to genetic instability and cancer development. Several genes related to inherited cancers have been identified on leukemia, certain childhood tumors, colon and especially breast and ovarian cancer. [10]. For example, germline mutations in breast cancer gene 1 [BRCA1] represent a predisposing genetic factor in $15-45 \%$ of hereditary breast cancers. Female mutation carriers have a $60-80 \%$ lifetime risk for developing breast cancer $[11,12]$ and a $20-40 \%$ lifetime risk of developing ovarian cancer [13-15]. Furthermore, mutations in APC gene or mismatch DNA repair genes lead to two different types of inherited colon cancer

${ }^{\star}$ Correspondence to: Suleyman Kaleli, Faculty of Medicine, Department of Medical Biology, Sakarya University, 54187, Sakarya Turkey, Tel: +902642953117; E-mail: skaleli@sakarya.edu.tr

This manuscript was presented as oral presentation in ISEM2016, 3rd International Symposium on Environment and Morality, 4-6 November 2016, Alanya - Turkey

Key words: environment, carcinogens, cancer, DNA, mutation

Received: April 17, 2018; Accepted: May 04, 2018; Published: May 07, 2018 
familial adenomatous polyposis [FAP] and hereditary non-polyposis colorectal cancer [HNPCC], respectively [16].

\section{The relationship between cancer and carcinogens}

Environmental factors such as X-rays, gamma rays, radiation emitted from radioactive materials, aniline type dyes, cigarette, free radicals, asbestos, silica dust, air pollution, food additives, various drugs, some of the chemicals used in perfumes, oncogenic viruses and bacteria play an important role in the risk of cancer. [10].

\section{Radiation}

Radiation is classified into two fundamental categories as nonionizing and ionizing radiation. Ionizing radiation is identified as $\mathrm{X}$-rays, which forms electrically charged particles or ions [17]. X-rays and gamma rays are especially used for medical imaging $[16,19]$. Computed tomography [CT] is a radiological method that generates a three-dimensional image for the diagnosis of various diseases [20]. It has been described in several studies that diagnostic X-rays lead to cause mutations and up to $10 \%$ of invasive cancers are related to radiation exposure [21-26]. With regard to this concern, large cohorts of patients treated with radiotherapy for cervical cancer, breast cancer, Hodgkin lymphoma, testicular cancer, and childhood cancer have been followed for decades. Increased levels of screening in a radiationexposure is known of the risk of cancer incidence. In this respect, the biological impact can change according to the dose equivalent of radiation [27-30].

\section{Heavy metals}

Exposure to various chemicals and heavy metals depending on exposed dose, genetics, people's immune resistance and overall health status, age, the level of nutrition has been associated with risk of different cancers, including breast cancer, pancreatic, lung cancer, and gallbladder cancer etc. [10]. When metals get into the body through air, food, water, or dermal exposure, they exert their enzymatic and genotoxic effects on different organs [31]. Some heavy metals such as arsenic, cadmium, chromium, nickel, and zinc are known as developing cancer. They bind to vital cellular components, such as structural proteins, enzymes, and nucleic acids [32]. For instance, the effect of cadmium on the lung and prostate cancer has been determined [33]. The toxicological effects of zinc were determined in experimental animals [34]. Additionally, there may be a relationship between exposure to certain metal compounds and the risk of breast cancer [35]. However, there is urgently needed the experimental animal studies, and epidemiologic studies associated metals with cancer.

\section{Cigarette}

Chemicals in cigarette smoke cause DNA damage and have been increasing the risk of various cancers, particularly primary lung cancer [3-10]. It is known that nearly 9 out of 10 lung cancers are caused by cigarette smoking. Cigarettes cause about 1.5 million deaths from lung cancer per year and it is estimated that a number will rise to nearly 2 million per year by the 2020s or 2030s [6].

\section{Foods and nutrition}

Dietary factors have been associated with $30 \%$ of cancers in Western countries. In fact, making diet is a second factor after tobacco as a preventable cause of cancer. The effects diet on cancer risk in developing countries has been considered around 20\% [37]. On the other hand, some parts of additives have carcinogenic effects. For example, the dulce, cinnamyl anthranilate and thiourea like synthetic additives, which cause liver cancer, have been identified in some experiments and thus, they are forbidden to use these substances in foods [3840]. However, some substances, including nitrite salts, sodium nitrite [E250] or potassium nitrite [E249] have been used despite of increasing the risk of cancer. Meat products such as sausage as antibacterial and color holder include these substances. This type of processed meat products increases the risk of bowel cancer by $21 \%$ [41]. Unfortunately, an excess of consumption of sugar and salt, which are the two main foods, causes obesity and an increase in insulin and so, higher level of these substances indirectly increase the risk of cancer [42]. Besides, aflatoxins are found in the groundnut, pulses, oilseeds and grains and they increase the risk of hepatocellular carcinoma [11].

\section{Free radicals and ROS}

Free radicals and ROS have been associated with the increased risk of cancer [12]. Particularly free radicals cause cancer and atherosclerosis diseases. The free radicals lead to cancer initiation and promotion by chromosomal defects and oncogene activation. On the other hand, ROS, such as super oxide anion, hydrogen peroxide, hydroxyl radical, and nitric oxide and their biological metabolites also play an important role in carcinogenesis. ROS induce DNA damage including double strand break, base modification and DNA protein cross-links [43].

\section{Air pollution}

Emissions from motor vehicles, industrial processes, power generation, the household combustion of solid fuel, and other sources pollute the ambient air across have global effect in the world. The chemical and physical features of ambient air pollution can vary according to sources of pollution, climate, and meteorology. However, the specific chemicals in the air pollution are known to be carcinogenic to humans. In 1971, the US Clean Air Act was established and ozone, particulate matter, sulfur dioxide, nitrogen dioxide, carbon monoxide and lead were defined as air pollutants. Furthermore, 189 toxic and hazardous air pollutants have been identified [44]. Exposure to ambient fine particles [PM2.5] was recently estimated to have contributed 3.2 million premature deaths worldwide in 2010, due largely to cardiovascular disease, and 223.000 deaths from lung cancer [45, 46].

These air pollutants cause to acute illness such as vomiting, chronic diseases such as cancer, as well as immunologic, neurologic, reproductive, developmental and respiratory diseases. Exposure of these chemicals increases the risk of pleural and peritoneal tumors and lung cancer incidence [47-50].

\section{Oncogenic viruses}

Oncoviruses or tumor viruses are a general term used for viruses. This term began to use in 1950-60 years to show acute conversion. Nowadays, it means any virus containing DNA or RNA genome and thus, it is synonymous with "tumor virus" or "cancer virus". However, the majority of viruses does not cause cancer in humans or animals [51]. Oncoviruses such as Hepatitis viruses [HBV, HCV], Human papilloma viruses [HPV], Kaposi sarcoma-associated herpesvirus [HHV-8], Human T-Lymphotropic Virus [HTLV] and Epstein-Barr virus [EBV] have been associated with the risk of cancer [13]. It is estimated that viral infections contribute to $15-20 \%$ of all human cancers [52]. Thus, these cancers [e.g. Papillomavirus vaccines] can be prevented by vaccination and can be detected with a simple blood test and can be treated with antiviral compounds.

\section{Discussion}

New areas of cancer research are focusing on the potential for pollutants to interact with one another and with genetic factors. The 
exact cause or causes of cancer have not known exactly. However, certain genes that tend to cancer interact with some environmental factors such as viruses, exposure to radiation, various chemicals and pollutants are related to increasing the risk of cancer. Carcinogens have an effect on damaging DNA, disrupting hormones, inflaming tissues, or switching genes on or off [53]. On the other hand, there is substantial evidence that synergism between two different exposures can cause some cancers. Asbestos, for example, enhances the carcinogenicity of tobacco smoke, so the rate of lung cancer was especially high among people who smoked and were exposed to asbestos in their workplaces [53]. Consequently, the environment is often used with a broad scope in the medical literature and it is known that the environmental factors have been increased the risk of cancers [54]. Thus, more studies that are detailed are needed to determine the exact effects of environmental factors on cancer development.

\section{Conclusion}

People can avoid some cancer-causing exposures, such as tobacco smoke and the sun rays. However, other environmental risk factors including air, water, food pollutants cannot be prevented due to consisting of normal life. It is known that environmental factors may cause or contribute to the development of cancer. However, studies that are more detailed are needed to determine the exact cause of a health effect. As a result, when a large number of studies have been performed, association the actual risk of cancer with the environmental risk factors can be clearer.

\section{References}

1. Futreal PA, Kasprzyk A, Birney E, Mullikin JC, Wooster R, et al. (2001) Cancer and genomics. Nature 409: 850-852. [Crossref]

2. Stratton MR, Campbell PJ, Futreal PA (2009) The cancer genome. Nature 458: 719724. [Crossref]

3. Williams GM (2001) Mechanisms of chemical carcinogenesis and application to human cancer risk assessment. Toxicology 166: 3-10. [Crossref]

4. Williams G M (1979) Review of in vitro test systems using DNA damage and repair for screening of chemical carcinogens. J Assoc Official Anal Chemists 62: 857-863.

5. Williams G M (1985) Genotoxic and epigenetic carcinogens, In: F. Homburger (ed.), Safety Evaluation and Regulation of Chemicals 2. Impact of Regulations-Improvement of Methods, Basel: Karger: 251-256.

6. Williams G M (1987) DNA reactive and epigenetic carcinogens, In: J.C. Barrett, (ed.), Mechanisms of Environmental Carcinogenesis, Vol 1: Role of Genetic and Epigenetic Changes, Boca Raton, FL: CRC Press, Inc:113-127.

7. Williams GM (1987) Definition of a human cancer hazard. In: Nongenotoxic Mechanisms in Carcinogenesis. New York: Banbury Report 25, Cold Spring Harbor Laboratory: 367-380

8. Williams GM (1992) DNA reactive and epigenetic carcinogens. Exp Toxicol Pathol 44: 457-464. [Crossref]

9. "Tag: Early diagnosis of cancer", https://sanjivharibhakti.wordpress.com/tag/earlydiagnosis-of-cancer/ (Accessed: Mar 11, 2017)

10. Yokus B, Ülker DU (2012) Kanser Biyokimyasi. Dicle Üniv Vet Fak Derg 1: 7-18.

11. Aksoy U, Eltem R, Meyvaci KB, Altindisli A, Karabat S (2007) Five-year survey of ochratoxin A in processed sultanas from Turkey. Food Addit Contam 24: 292-296. [Crossref]

12. Lobo V, Patil A, Phatak A, Chandra N (2010) Free radicals, antioxidants and functional foods: Impact on human health. Pharmacogn Rev 4: 118-126. [Crossref]

13. Bougie O, Weberpals JI (2011) Clinical Considerations of BRCA1 - and BRCA2 -Mutation Carriers: A Review. Int J Surg Oncol 2011: 374012. [Crossref]

14. King MC, Marks JH, Mandell JB (2003) Breast and ovarian cancer risks due to inherited mutations in BRCA1 and BRCA2. Science 302: 643-646. [Crossref]

15. Antoniou A, Pharoah PD, Narod S, Risch HA, Eyfjord JE, et al. (2003) Average risks of breast and ovarian cancer associated with BRCA1 or BRCA2 mutations detected in case Series unselected for family history: a combined analysis of 22 studies. Am J Hum Genet 72: 1117-1130. [Crossref]

16. Vogelstein B, Kinzler KW (1993) The multistep nature of cancer. Trends Genet 9: 138 141. [Crossref]

17. Dauda S (2011) Dicle Üniversitesi Tip Fakültesi Biyofizik Anabilim Dalinda "Iyonlastirmayan Elektromanyetik Alanlar Ve Ihsan Sagligi" Üzerine Yapilmis Arastirma Sonuçlarinin Degerlendirilmesi ÇEVRE ve Halk Sagligi Için Emanet 2011, Elektromanyetik Alanlar ve Etkileri Sempozyumu 7 - 8 Ekim, Istanbul: 233-237.

18. Elektromanyetik Kirlilik ve Saglik. Kent ve Elektromanyetik Dalga Kirliligi Sempozyumu Bildiri Kitabi, Antalya, 2010; 15-22.

19. 2007 Recommendations of the International Commission on Radiological Protection (Users Edition)" ICRP Publication 103. Ann ICRP 37: 1-332. [Crossref]

20. Radiation protection in Medicine ICRP Publication 105. Ann ICRP 37: 1-63. [Crossref]

21. Radiation protection, X-rays. http://www.arpansa.gov.au/radiationprotection/ Basics/ xrays.cfm (Accessed: May 29, 2016).

22. Huang BS, Law MWM, Khong PL (2009) Whole-Body PET/CT Scanning: Estimation of Radiation Dose and Cancer Risk. Radiology 251: 166-174. [Crossref]

23. National Toxicology Program, U.S. Department of Health and Human Services, Eleventh Edition of the Report on Carcinogens, January 31, 2005.

24. Dedic S, Pranjic N (2009) Lung cancer risk from exposure to diagnostic x- rays. Health Med 3: 307-313.

25. Herfarth H, Palmer L (2009) Risk of Radiation and Choice of Imaging. Dig Dis 27: 278-284. [Crossref]

26. Heyes GJ, Mill AJ, Charles MW (2009) Mammography-oncogenecity at low doses. $J$ Radiol Protect 29: A123-A132. [Crossref]

27. Gilbert ES (2009) Radiation-related risk of solid cancers appears to persist throughout life. Int J Radiation Biol 85: 467-482.

28. Dawson P, Punwani S (2009) The thyroid dose burden in medical imaging: A reexamination. Eur J Radiol 69: 74-79. [Crossref]

29. Wakeford R (2008) Childhood leukemia following medical diagnostic exposure to ionizing radiation in utero or after birth. Radiat Prot Dosimetry 132: 166-174. [Crossref]

30. Myles P, Evans S, Lophatananon A, Dimitropoulou P, Easton D, et al. (2008) Diagnostic radiation procedures and risk of prostate cancer. Br J Cancer 98: 1852-1856. [Crossref]

31. Gilbert ES (2009) Ionizing Radiation and Cancer Risks: What Have We Learned From Epidemiology? Int J Radiat Biol 85: 467-482. [Crossref]

32. Chhabra D, Oda K, Jagannath P, Utsunomiya H, Takekoshi S, et al. (2012) Chronic Heavy Metal Exposure and Gallbladder Cancer Risk in India, a Comparative Study with Japan. Asian Pac J Cancer Prev 13: 187-190. [Crossref]

33. Antwi SO, Eckert EC, Sabaque CV, Leof ER, Hawthorne KM, et al. (2015) Exposure to environmental chemicals and heavy metals, and risk of pancreatic cancer. Cancer Causes Control 26: 1583-1591. [Crossref]

34. Verougstraete V, Lison D, Hotz P (2003) Cadmium, Lung and Prostate Cancer: A Systematic Review of Recent Epidemiological Data. J Toxicol Environ Health B Crit Rev 6: 227-256. [Crossref]

35. Vural H (1993) Agir metal iyonlarinin gidalarda olusturdugu kirlilikler. Çevre Dergis $8: 3-8$

36. Florea M, Büsselberg D (2011) Metals and Breast Cancer: Risk Factors or Healing Agents? J Toxicol 8: 1-8. [Crossref]

37. Proctor NR (2012) The history of the discovery of the cigarette lung cancer link: evidentiary traditions, corporate denial, global toll. Tob Control 21: 87-91. [Crossref]

38. Key TJ, Schatzkin A, Willett WC, Allen NE, Spencer EA, et al. (2004) Diet, nutrition and the prevention of cancer. Public Health Nut 7: 187-200. [Crossref]

39. Czene K, Lichtenstein P, Hemminki K (2002) Environmental and heritable causes of cancer among 9.6 million individuals in the Swedish Family-Cancer Database. Int $J$ Cancer 99: 260-266. [Crossref]

40. Anand P, Kunnumakara AB, Sundaram C, Harikumar KB, Tharakan ST, et al. (2008) Cancer is a preventable disease that requires major lifestyle changes. Pharm Res 25: 2097-2116. [Crossref]

41. Boffetta P, Nyberg F (2003) Contribution of environmental factors to cancer risk. $B r$ Med Bull 68: 71-94. [Crossref] 
42. Irigaray P, Newby JA, Clapp R, Hardell L, Howard V, et al. (2007) Lifestyle-related factors and environmental agents causing cancer: an overview. Biomed Pharmacother 61: 640-658. [Crossref]

43. Kushi LH, Doyle C, McCullough M, Rock CL, Demark-Wahnefried W, et al. (2006) American Cancer Society Guidelines on Nutrition and Physical Activity for Cancer Prevention: Reducing the Risk of Cancer with Healthy Food Choices and Physical Activity. CA Cancer J Clin 56: 254-281. [Crossref]

44. Hussain SP, Hofseth LJ, Harris CC (2003) Radical causes of cancer. Nat Rev Cancer 3: 276-285. [Crossref]

45. Burrows M (2009) The Clean Air Act: Citizen Suits, Attorneys' Fees, and the Separate Public Interest Requirement. Envtl Aff 36.

46. Air pollution and cancer. https://www.iarc.fr/en/publications/books/sp161/ Air Pollutionand Cancer16.pdf (accessed May 18, 2016).

47. Brown RC1, Hoskins JA, Miller K, Mossman BT (1990) Pathogenetic mechanisms of asbestos and other mineral fibres. Mol Aspects Med 11: 325-349. [Crossref]
48. Peto J, Seidman H, Selikoff IJ (1982) Mesothelioma mortality in asbestos workers: Implications for models of carcinogenesis and risk assessment. Br J Cancer 45: 124 132. [Crossref]

49. Maghissi AA, Seiler MC (1989) Enhancement of exposure to radon progeny as a consequence of passive smoking. Environ Int 15: 261-264.

50. Kunz E, Sevc J, Placek V, Horácek J (1979) Lung cancer in man in relation to differen time distribution of radiation exposure. Health Phys 36: 699-706. [Crossref]

51. Onkovirüs. https://tr.wikipedia.org/wiki/Onkovir\%C3\%BCs (accessed May 20, 2016).

52. Margaret EM, Munger K (2007) Viruses associated with human cancervol. Biochim Biophys Acta 1782: 127-150. [Crossref]

53. How Many Cancers Are Caused by the Environment? http://www.scientificamerican. $\mathrm{com} /$ article/how-many-cancers-are-caused-by-the-environment/ (accessed May 13, 2016).

54. L. Tomatis (1990) Cancer: Causes, occurrence and control. IARC Scientific Publications, 100. International Agency for Research on Cancer, Lyon.

Copyright: (2018 Kaleli S. This is an open-access article distributed under the terms of the Creative Commons Attribution License, which permits unrestricted use, distribution, and reproduction in any medium, provided the original author and source are credited. 